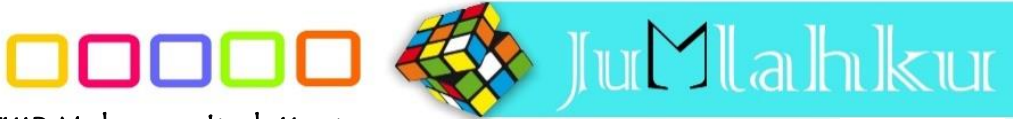 \\ E-ISSN : 2654-833X \\ P-ISSN : 2443-3500
}

Jurnal Matematika Ilmiah STKIP Muhammadiyah Kuningan

Vol. 5 No.2 November 2019

\section{Penerapan Metode Problem Solving Berbantu Benda Konkret Untuk Meningkatkan Kemampuan Berpikir Kreatif Matematis Siswa}

\author{
Jihan Faridaha), Wahidin ${ }^{\text {b) }}$, Benny Hendrianac)
}

a) (Program Studi Pendidikan Matematika, Fakultas Keguruan dan IImu Pendidikan, Universitas Muhamadiyah Prof. DR. Hamka)

jihanfaridah4@gmail.com

b) (Program Studi Pendidikan Matematika, Fakultas Keguruan dan IImu Pendidikan, Universitas Muhamadiyah Prof. DR. Hamka) wahidinmtk@uhamka.ac.id

c) (Program Studi Pendidikan Matematika, Fakultas Keguruan dan Ilmu Pendidikan, Universitas Muhamadiyah Prof. DR. Hamka) benny_hendriana@uhamka.ac.id

\begin{tabular}{l}
\hline \multicolumn{1}{c}{ Article Info } \\
\hline Keywords : Concrete \\
Objects, Creative Thinking \\
Ability, HOTS, Problem \\
solving
\end{tabular}

Submited: $10 / 12 / 2019$

Published: 12/4/2019

\begin{abstract}
The purpose of the implementation of this research is learning by applying the method of problem solving with the help of concrete objects to be able to improve thinking skills, especially on students' mathematical creative thinking abilities. The research method used is classroom action research (CAR). Subject of this study was grade VII-F students of Junior High School 200 Jakarta. In testing the validity using Pearson product-moment correlation as many as 4 description test questions with 4 valid questions in the Pre Cycle, 5 description test questions with 4 valid questions and 1 drop question in Cycle I, and as many as 7 test questions with 6 valid questions and 1 about drop. While the reliability test using Cronbach Alpha obtained $\boldsymbol{r}_{\text {count }}=\boldsymbol{r}_{\mathbf{1 1}}=\mathbf{0 , 3 5 4}>\mathbf{0 , 3 3 9}=\boldsymbol{r}_{\text {tabel }}$ in the Pre Cycle, then in the Pre cycle obtained a reliable instrument. In Cycle I obtained $\boldsymbol{r}_{\text {count }}=$ $\boldsymbol{r}_{\mathbf{1 1}}=\mathbf{0 , 3 1 5}>\mathbf{0 , 3 1 2}=\boldsymbol{r}_{\text {tabel }}$, then in Cycle I obtained a reliable instrument. Then in Cycle I/ obtained $r_{\text {count }}=\boldsymbol{r}_{\mathbf{1 1}}=\mathbf{1}, \mathbf{1 7 4}>$ $\mathbf{0 , 3 1 2}=\boldsymbol{r}_{\text {tabel }}$, then in Cycle $/ /$ obtained a reliable instrument. The results obtained from this study indicate that the application of problem solving methods with the aid of concrete objects can improve the mathematical creative thinking ability of junior high school students.
\end{abstract}


Kata Kunci: Benda Konkret, HOTS, Kemampuan Berpikir Kreatif, Problem solving

\section{Abstrak}

Tujuan dari pelaksanaan penelitian ini adalah pembelajaran dengan menerapkan metode problem solving dengan berbantu benda konkret untuk dapat meningkatkan kemampuan berpikir khususnya pada kemampuan berpikir kreatif matematis peserta didik. Metode penelitian yang dugunakan yaitu penelitian tindakan kelas (PTK). Subjek dalam penelitian ini adalah siswa kelas VII-F SMP Negeri 200 Jakarta. Pada uji validitas dengan menggunakan korelasi product-moment Pearson sebanyak 4 soal tes uraian dengan 4 soal valid pada Pra Siklus, 5 soal tes uraian dengan 4 soal valid dan 1 soal drop pada Siklus I, dan sebanyak 7 soal tes uraian dengan 6 soal valid dan 1 soal drop. Sedangkan pada uji reliabilitas menggunakan Alpha Cronbach memperoleh $r_{\text {hitung }}=r_{11}=0,354>0,339=r_{\text {tabel }}$ pada Pra Siklus, maka pada Pra siklus memperoleh instrumen yang reliabel. Pada Siklus I memperoleh $r_{\text {hitung }}=r_{11}=0,315>0,312=r_{\text {tabel }}$, maka pada Siklus I memperoleh instrument yang reliabel. Kemudian pada Siklus II memperoleh $r_{\text {hitung }}=r_{11}=1,174>0,312=r_{\text {tabel }}$, maka pada Siklus II memperoleh instrumen yang reliabel. Hasil yang diperoleh dari penelitian ini menunjukkan bahwa dengan penerapan metode problem solving dengan berbantu benda konkret dapat meningkatkan kemampuan berpikir kreatif matematis peserta didik SMP. 


\section{PENDAHULUAN}

Matematika adalah salah satu mata pelajaran yang tanpa kita sadari sudah dipelajari sejak belum masuk kedalam pendidikan formal. Seseorang sudah mulai mengenal angka maka pada saat itulah orang tersebut telah mempelajari matematika. Contohnya pendidikan formal pelajaran matematika ini telah dipelajari dari mulai TK, SD, SMP, SMA, sampai Perguruan Tinggi.

Hal ini dikemukakan oleh (Lince, 2016) mengungkapkan bahwa Mathematical as a subject, should be given to all student form primary schools to eqeip students with the ability to think logically, analytical, systematic, critical, and creative, as well as the ability tocooparate. Maksud dari penjelasan itu menjelaskan bahwa pelajaran matematika itu penting dan sudah diberikan dari sekolah dasar dimana matematika ini berguna untuk membekali siswa pada kemampuan berpikir logis, analitis, sistematis, kritis, dan kreatif serta kemampuan untuk saling bekerjasama.

Berpikir merupakan kegiatan mental yang dialami pada setiap orang, dimana pada kegiatan mental ini melibatkan kerja otak pada saat seseorang dihadapkan pada suatu permasalahan yang harus dipecahkan. Hal ini didukung oleh (Kuswana, 2011) yang menjelaskan bahwa sifat berpikir merupakan suatu keadaan mental dan dapat dipersepsikan serta diinterpretasikan. Pendapat lain juga menuturkan bahwa berpikir sebagai suatu kemampuan mental seseorang dapat dibedakan menjadi beberapa jenis, antara lain berpikir logis, analitis, sistematis, kritis, dan kreatif (Siswono, 2018). Sehingga dengan diberikannya kemampuan berpikir ini dapat digunakan dengan selayaknya dan juga sungguhsungguh, karena ini merupakan salah satu anugerah terbesar yang telah diberikan Allah SWT., kepada umatnya.

Menyedari pentingnya keaktifan dan kemandirian peserta didik dalam proses pembelajaran yang sedang berlangsung khususnya dalam pelajaran matematika. Sikap tersebut akan mendorong peserta didik dapat memperoleh pengetahuan atau ide/gagasan baru. Maka dari itu seorang guru tidak hanya bertugas sebagai pentransfer ilmu dan mengajar. Tetapi juga harus dapat menciptakan kelas yang aktif serta menumbuh kembangkan pola pikir siswa yang kreatif dalam belajar. Seperti yang dijelaskan oleh (Uno, Umar, \& Panjaitan, 2014) bahwa kreativitas sebagai proses kreatif dan ilmiah mulai dari menemukan masalah sampai dengan menyampaikan hasil. Berpikir kreatif merupakan cara berpikir matematis untuk dapat menyelesaikan masalah matematika. Hal ini didukung oleh (Faelosofi, 2017) yang menjelaskan bahwa kemampuan berpikir kreatif merupakan suatu tuntutan untuk bisa menciptakan suatu ide atau alternatif solusi sebagai upaya dalam

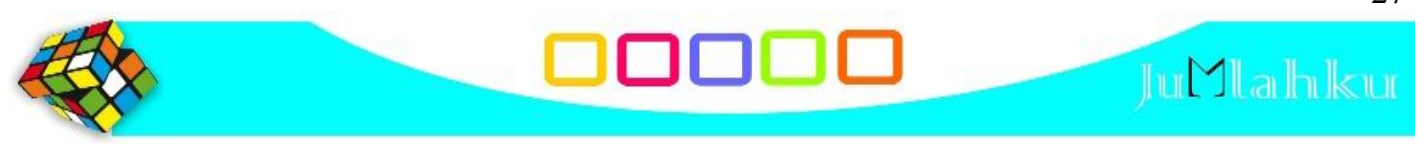


menyelesaikan masalah yang terjadi dalam kehidupan sehari-hari. Hal ini juga dikemukakan oleh (Lince, 2016) yang menuturkan bahwa jika siswa dapat sering menyelesaikan soal matematika secara rutin dan kemudian siswa tersebut dapat menyelesaikan soal matematika dengan cara yang berbeda dari apa yang telah diajarkan guru di kelas, maka siswa tersebut dapat dikatakan kreatif dalam matematika.

Kemampuan kreativitas pada siswa perlu dikembangkan agar dapat meningkatkan kemampuan berpikir kreatif berpikir kreatif matematis peserta didik. Karena dengan berpikir kreatif akan mendorong siswa menemukan ide/gagasan baru sehingga dapat lebih mudah dalam menghadapi permasalahan matematika. Hal ini juga didukung oleh (Firdaus dkk, 2018) yang menyatakan bahwa salah satu upaya meningkatkan kreativitas sebagai bekal hidup menghadapi berbagai tantangan, tuntutan, perubahan, dan perkembangan zaman adalah melalui pendidikan yang berikualitas, tanpa terkecuali dengan pendidikan matematika. Pendapat lainnya menjelaskan bahwa kemampuan berpikir kreatif merupakan suatu tuntutan untuk bisa menciptakan suatu ide atau alternatif solusi sebagai upaya dalam menyelesaikan masalah yang terjadi dalam kehidupan sehari-hari (Faelosofi, 2017).
Mengukur kemampuan berpikir kreatif siswa dapat berupa tes soal uraian. Dimana setiap soalnya mengandung indikator kemampuan berpikir kreatif. Indikator kemampuan berpikir kreatif ini dikemukakan oleh (Faelosofi, 2017) bahwa Indikator berpikir kreatif meliputi: (1) fluency: kemampuan mengemukakan jawaban/ide lebih dari satu terhadap masalah atau situasi matematis tertentu dengan lancar; (2) flexibility: kemampuan menghasilkan jawaban/ide bervariasi atau mengubah cara/pemikiran yang lain, dan (3) elaboration: (4) kemampuan membuat rincian gagasan dengan detail.

Menyedari pentingnya peran dari berpikir kreatif pada siswa, maka dari itu diperlukan metode pembelajaran yang cocok untuk meningkatkan kemampuan berpikir kreatif matematis siswa. Pemilihan metode pembelajaran matematika yang cocok sangat penting untuk mendukung proses pembelajaran sehingga dapat tercapainya tujuan pembelajaran. Guru juga harus kreatif dan inovatif dalam memilih metode pembelajaran sehingga dapat menciptakan suatu kelas yang menyenangkan. Siswa perlu dilatih untuk dapat mengasah kemampuan berpikir kreatif diantaranya dalam hal mengungkapkan pendapat/ide gagasan dengan caranya sendiri, dapat mengerjakan permasalahan matematika secara rinci dan jelas, tidak terpaku hanya dengan satu cara dan contoh yang 
didapat, dan lain sebagainya yang dapat mendorong siswa untuk belajar secara mandiri.

Metode pembelajaran yang dapat mendorong siswa untuk dapat belajar aktif dan kreatif dalam memecahkan masalah matematika yang menjadi pilihan peneliti yaitu metode problem solving. Metode problem solving merupakan metode pembelajaran yang mendorong siswa belajar secara mandiri untuk dapat memecahkan masalah. Hal ini juga dijelaskan pendapat lain oleh (Djamarah \& Zain, 2015) bahwa metode problem solving (metode pemecahan masalah) bukan hanya sekadar metode mengajar, tetapi juga merupakan suatu metode berpikir, sebab dalam metode problem solving dapat menggunakan metodemetode lainnya yang dimulai dengan mencari data sampai kepada menarik kesimpulan. Kegiatan siswa dalam problem solving dilakukan melalui prosedur: (1) mengidentifikasi penyebab masalah; (2) mengkaji teori untuk mengatasi masalah atau menemukan solusi; (3) memilih dan menetapkan masalah solusi yang paling tepat; (4) menyusun prosedur mengatasi masalah berdasarkan teori yang telah dikaji (Mulyatiningsih, 2011). Tugas guru dalam metode problem solving juga kembali dijelaskan oleh (Mulyatiningsih, 2011) bahwa tugas guru dalam metode problem solving adalah memberikan kasus atau masalah kepada siswa untuk dipecahkan.
Siswa ditugaskan guru untuk dapat memecahkan suatu masalah dengan cara atau pengetahuan secara mandiri. Sehingga dapat mengasah siswa untuk mengemukakan ide-ide/gagasan baru. Memecahkan suatu permasalahan diperlukan siswa yang kreatif. Sebagaimana yang telah dikemukakan oleh (Siswono, 2018) bahwa pemecahan masalah merupakan salah satu cara untuk mendorong kreativitas ataupun keterampilan berpikir kreatif siswa.

Langkah-langkah dalam pelaksanaan pembelajaran problem solving menurut Polya (dalam Firmansyah dkk, 2016) memaparkan bahwa model pembelajaran problem solving terdiri dari 4 langkah, yakni memahami masalah (understanding the problem), menyusun rencana pemecahan masalah (devising a plan), melaksanakan rencana penyelesaian (carrying out the plan), dan memeriksa kembali jawaban yang diperoleh (looking back). Pendapat lain (Shoimin, 2014) juga mengemukakan langkah-langkah pembelajaran problem solving sebagai berikut: (a) Masalah sudah ada dan materi diberikan; (b) Siswa diberi masalah sebagai pemecahan/diskusi, kerja kelompok; (c) Masalah tidak dicari (sebagaimana pada prolem based learning dari kehidupan mereka seharihari; (d) Siswa diberikan kesimpulan dari jawaban yang diberikan sebagai hasil akhir; (e) Penerapan pemecahan terhadap masalah yang dihadapi

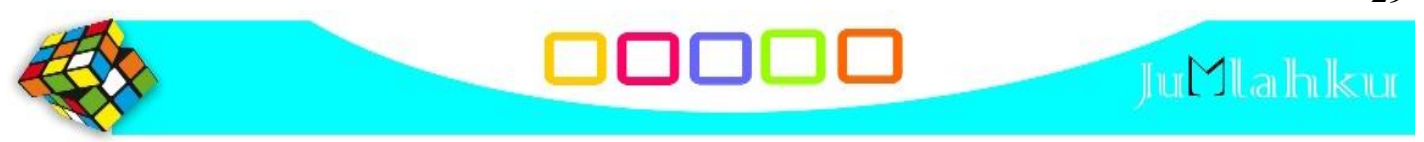


sekaligus berlaku sebagai pengujian kebenaran pemecahan tersebut untuk dapat sampai kepada kesimpulan.

Kelebihan metode problem solving juga dikemukakan oleh (Shoimin, 2014) diantaranya (1) Dapat melatih dan membiasakan siswa untuk menghadapi dan juga memecahkan masalah secara terampil; (2) Dapat mengembangkan kemampuan berpikir siswa secara kreatif; (3) Melatih siswa untuk dapat memecahkan masalahnya; (4) Melatih siswa untuk mendesain suatu penemuan;

(5) Berpikir dan bertindak secara kreatif;

(6) Memecahkan permasalahan yang dihadapinya secara realistis; (7) Menjadikan siswa mampu mengidentifikasi dan melakukan penyelidikan; (8) Menafsirkan dan mengevaluasi hasil pengamatan; (9) Merangsang perkembangan kemajuan berpikir siswa untuk menyelesaikan masalah yang dihadapi secara tepat, dan (10) Menjadikan pendidikan sekolah lebih relevan dalam kehidupan, khususnya dunia kerja. Pendapat lain mengenai keunggulan pembelajaran problem solving juga dikemukakan oleh Hayloct \& Thangata (dalam (Setianingsih, 2016)) bahwa keunggulan pendekatan problem solving, yaitu dapat mengembangkan sikap positif siswa terhadap proses pembelajaran matematika.

Beberapa pendapat yang telah memaparkan kelebihan dari problem solving, namun juga terdapat kekurangannya. Seperti halnya metode lain, bahwa metode problem solving juga memiliki kelemahan yang telah dipaparkan oleh (Shoimin, 2014) yaitu sebagai berikut: (1) Memerlukan cukup banyak waktu; (2) Melibatkan orang lebih banyak; (3) Dapat mengubah yang sudah menjadi kebiasaan siswa belajar dengan mendengar dan mendapatkan informasi dari guru; (4) Dapat diterapkan secara langsung seperti untuk memecahkan suatu permasalahan; (5) Untuk beberapa pokok bahasan sangat sulit menerapkan metode ini; (6) Memelurkan alokasi waktu yang lebih banyak jika dibandingkan dengan metode pembelajaran lainnya; (7) Kesulitan yang mungkin dihadapi.

Metode problem solving bertujuan untuk mendorong siswa untuk belajar mandiri serta aktif dalam menyelesaikan permasalah yang terjadi dalam pembelajaran matematika. Maka dari itu perlu adanya media untuk menjebatani atau membantu kegiatan belajar. Selain dapat membantu dalam proses pembelajaran, media pembelajaran ini juga dapat membuat suasana belajar tidak membosankan. Kata media berasal dari bahasa Latin dan merupakan bentuk jamak dari kata medium yang secara harfiah berarti perantara atau pengantar (Sadiman \& dkk, 2014). Pendapat lain mengenai pengertian media juga dikemukakan oleh (Handayani, Supriadi, \& Marlena, 2018) bahwa media merupakan suatu perantara atau 30 
pengantar, media pembelajaran adalah sarana penyampaian pesan pembelajaran terkait dengan model pembelajaran langsung di mana dosen atau guru berperan sebagai penyampai informasi. Penggunaan media pembelajaran juga membantu mempermudah pemahaman siswa dan membuat proses pembelajaran menjadi lebih efektif dan efisien (Hendriana, 2019).

Media yang digunakan dalam membantu pembelajaran problem solving yaitu benda konkret. Benda konkret merupakan salah satu media pembelajaran yang dapat mudah kita temukan keberadaannya. Penggunaan benda konkret dalam pembelajaran akan terasa lebih berkesan dan mendalam pada proses pembelajaran. Karena benda konkret ini memberikan pengalaman nyata yang keberadaannya terdapat di lingkungan sekita. Sehingga penggunaan benda konkret ini membuat kegiatan belajar lebih menyenangkan karena mendapati pengalaman nyata dan baru.

Penguatan dalam penggunaan benda konkret ini juga didukung oleh pendapat (Sudjana \& Rivai, 2010) bahwa menggunakan benda-benda nyata atau makhluk hidup (real life materials) dalam pengajaran sering kali paling baik, dalam menampilkan benda-benda nyata tentang ukuran, suara, gerak-gerik, permukaan, bobot badan, bau serta manfaatnya. Pemilihan media pembelajaran yang tepat dapat membantu proses pembelajaran berjalan dengan baik dan efektif. Sehingga media pembelajaran juga dapat berfungsi sesuai dengan manfaatnya, salah satunya yaitu sebagai alat bantu dalam kegiatan belajar. Media pembelajaran juga dapat membuat siswa menjadi kreatif dan pembelajaran menjadi menyenangkan.

\section{METODE}

Jenis penelitian ini adalah penelitian tindakan kelas (PTK) yang telah dilaksanakan pada bulan Maret sampai April 2019. Tindakan penelitian ini lebih ditekankan pada penerapan metode problem solving berbantu benda konkret untuk meningkatkan kemampuan berpikir kreatif matematis siswa pada materi garis dan sudut. Subyek penelitian ini adalah kelas VII-F di SMP Negeri 200 Jakarta yang berjumlah 33 orang. Terpilinnya salah satu kelas tersebut karena saran dari guru matematika kelas VII dan pertimbangan peneliti bahwa kelas tersebut memerlukan metode lain agar dapat mengembangkan serta meningkatkan kemampuan berpikir kreatif matematisnya. Data penelitian diperoleh melalui tes kemampuan komunikasi matematis siswa, observasi, dan wawancara. Prosedur penelitian menggunakan model PTK menurut Kemmis \& Mc. Taggart dengan menggunakan sistem spiral refleksi diri yang dimulai dengan rencana (planning), tindakan (acting), pengamatan 
(observing), refleksi (reflecting). Indikator keberhasilan dalam penelitian ini adalah jika $80 \%$ dari total keseluruhan siswa memperoleh skor kemampuan berpikir kreatif minimal $70 \%$ dari skor maksimal.

\section{HASIL DAN PEMBAHASAN Pra Siklus}

Observasi dilaksanakan peneliti mulai tanggal 8 Desember 2018 sampai dengan 11 Desember 2018. Data awal yang diperoleh melalui wawancara bersama guru matematika kelas VII-F mengenai informasi kondisi kelas dan gaya belajar peserta didik sebagai data awal sebelum dilaksanakannya penelitian. Wawancara dan observasi dalam kelas dilaksanakan pada tanggal 10 Desember 2018. Informasi yang diperoleh terkait penggunaan metode dan media pembelajaran dari guru matematika kelas VII-F. Metode pembelajaran serta media pembelajaran akan diterapkan hanya pada pokok bahasan tertentu (jika dibutuhkan). Guru lebih menerapkan cara mengajar dengan metode ceramah. Untuk membuat peserta didik turut aktif dalam proses pembelajaran matematika yang sedang berlangsung. Guru menyiapkan beberapa pertanyaan yang bersifat membangun untuk dapat mengetahui sejauh mana peserta didik memahami materi yang telah dipaparkan. Setelah memberikan penjelasan, guru memberi kesempatan kepada peserta didik untuk bertanya bila belum memahaminya. Setelah itu peserta didik diberikan tugas untuk melatih pengetahuan terkait materi yang sedang dibahas.
Berdasarkan pengamatan, guru matematika kelas VII-F menguasai materi dengan baik dan dapat mengkondisikan peserta didik sehingga dalam proses pembelajaran dapat terfokuskan. Guru lebih banyak menjadi subjek sedangkan peserta didik menjadi objek. Beberapa peserta didik terlihat pasif dan kurang percaya diri. Namun sebagian peserta didik lainnya dapat merespon dengan baik setiap pokok bahasan. Kemudian dilanjutkan pada hari berikutnya yaitu tes awal untuk mengukur kemampuan berpikir kreatif matematis peserta didik kelas VII-F. Hasil tes awal yang diperoleh dari presentase nilai keseluruhan kelas VII-F menunjukan bahwa kemampuan berpikir kreatif siswa masih rendah, yaitu $36,36 \%$.

\section{Siklus I}

\section{a. Tahap Perencanaan}

Tahap perencanaan sebanyak empat pertemuan dengan tujuan pembelajaran yang akan dicapai yaitu siswa mampu mengembangkan kemampuan berpikir kreatif matematisnya. Maka guru mempersiapkan perangkat pembelajaran berupa RPP, buku paket siswa kelas VII semester genap kurikulum 2013 edisi revisi 2017 sebagai modul pembelajaran yang akan digunakan untuk membantu dalam proses pembelajaran, benda konkret, Lembar Kegiatan Siswa (LKPD), tes formatif uraian yang bertujuan untuk mengukur serta mengevalusi kemampuan peserta didik dalam setiap pertemuan, dan instrumen kemampuan berpikir kreatif matematis siswa. Guru juga menyiapkan lembar observasi untuk 
mengamati aktivitas siswa dalam proses pembelajaran, lembar observasi untuk mengamati aktivitas guru dalam melaksanakan proses pembelajaran, dan catatan lapangan. Hal ini bertujuan sebagai evaluasi bagi peneliti dalam melaksanakan penelitian yang telah diamati oleh oberver.

\section{b. Tahap Pelaksanaan}

Siklus pertama guru mengajarkan pokok bahasan tentang hubungan antara garis yang mana pada poin pertama meliputi pemahaman konsep kemudian menentukan hubungan antar garis, setelah itu membagi ruas garis menjadi beberapa bagian sama panjang, dan terakhir mengenai pengenalan sudut. Proses pembelajaran setiap pertemuan dilaksanakan dengan mengacu pada RPP yang telah disusun agar pelaksanaan sesuai dengan apa yang sudah direncanakan. Peneliti membagi siswa menjadi beberapa kelompok, dimana masing-masing kelompok berisi 3-4 siswa dan duduk saling berhadapan. Selanjutnya peneliti menanyakan pertanyaan yang bersifat esensial untuk mengeksplor pengetahuan peserta didik dalam proses belajar. Pertanyaan yang diajukan kepada peserta didik yang masih berkaitan dalam kehidupan sehari-hari atau berupa benda-benda yang berada disekitarnya. Peneliti mengkonfirmasi jawaban peserta didik tersebut dan menambahkan sedikit penjelasan sebagai pengetahuan awal peserta didik menganai materi yang akan dibahas.

Siswa diberikan benda konkret seperti manik-manik, benang, tusuk sate, dan kertas origami yang bermaksud untuk membuat peserta didik bertanya tentang benda-benda konkret yang diberikan setelah peserta didik mengamatinya. Untuk dapat memecahkan masalah yang diberikan oleh peneliti melalui benda konkret. Peneliti juga memberikan Lembar Kerja Siswa (LKPD) yang memberikan ruang kepada siswa untuk mengembangkan kemampuan berpikir kreatif matematis dalam memecahkan masalah matematika. Setiap kelompok juga diberikan benda konkret untuk membentuk melaksanakan perencanaan masalah yang diperoleh. Siswa melakukan diskusi kelompok untuk menyelesaikan suatu masalah dengan cara menyusun rencana dengan menyiapkan berbagai kemungkinan yang telah dijelaskan melalui langkah-langkah didalam LKPD.

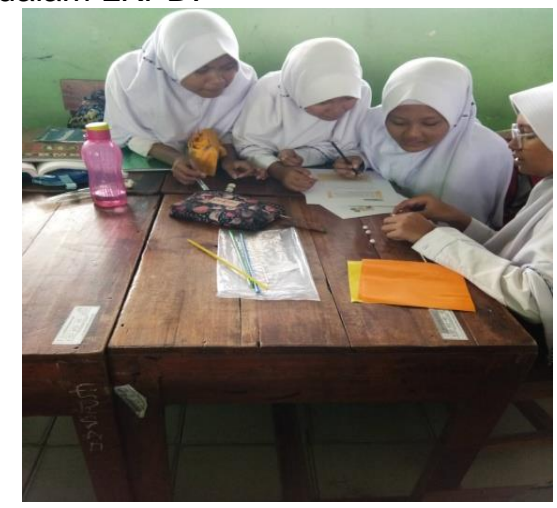

Gambar 1. Proses diskusi siswa dan perencanaan pemecahan masalah

Setelah rencana sudah tersusun siswa kembali membuktikan melalui benda konkret yang telah disediakan kemudian menggambarkan hasil yang didapat pada LKPD dan mempresentasikannya di depan kelas. Setelah semua selesai memaparkan hasil

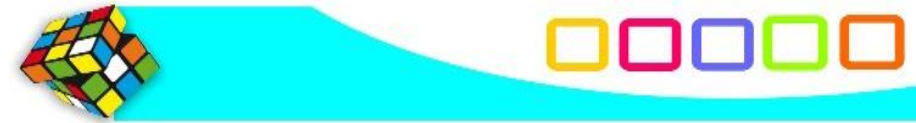


diskusinya kemudia siswa membuat kesimpulan dari pemasalahanpermasalahn yang diberikan melalui Lembar Kerja Siswa (LKPD).

\section{c. Tahap Pengamatan}

Pada tahapan ini peneliti dibantu oleh dua orang guru yang bertindak sebagi kolaborator dan observer. Tahap pengamatan ini dilakukan peneliti pada saat tindakan berlangsung, kolaborator turut membantu peneliti dalam pengamatan segala tindakan aktivitas peserta didik selama proses pembelajaran berlangsung. Pada awal penggunaan metode pembelajaran Problem solving, observer menyampaikan bahwa dalam pengelolaan kelas kurang optimal sehingga kondisi kelas kurang kondusif. Observer juga menyampaikan bahwa masih ada langkah-langkah pembelajaran yang belum maksimal dan peserta didik terlihat belum terbiasa dengan penerapan tindakan yang dilakukan peneliti.

\section{d. Tahap Refleksi}

Berdasakan data yang diperoleh dari tahap observasi melalui pelaksanaan kegiatan belajar pada Siklus I, sebagai berikut:

1. Siswa belum terbiasa dengan metode pembelajaran Problem solving

2. Beberapa siswa masih pasif dalam proses pembelajaran berlangsung

3. Kurangnya partisipasi siswa dalam berdiskusi kelompok seperti terdapat beberapa kelompok yang mengerjakannya hanya seorang atau dua orang sedangkan yang lainnya hanya berdiskusi dengan topik diluar pembahasan atau melakukan aktifitas yang tidak ada kaitannya dengan materi pembelajaran

4. Terdapat perbedaan dari segi rajin dan aktif antara kelompok satu dengan kelompok lainnya

5. Banyaknya siswa yang tidak memperhatikan presentasi yang dilakukan oleh temannya sehingga pada saat tes formatif berlangsung tidak dapat mengerjakan secara maksimal

6. Cukup memakan banyak waktu sehingga respon siswa pada saat mengerjakan tes formatif terburu-buru.

7. Hasil tes kemampuan berpikir kreatif matematis siswa pada siklus I terjadi peningkatan, namun masih dalam kategori kurang. Dimana rata-rata 69,82 dan presentase siswa yang telah mencapai indikator keberhasilan yaitu $63,64 \%$ dan belum mencapai ketentuan.

Hasil Siklus I ini sudah terjadi peningkatan jika dibandingkan dengan kemampuan berpikir kreatif matematika sebelum adanya tindakan dengan metode Problem solving berbantu benda konkret namun belum mencapai target yang telah manjadi pertimbangan peneliti. Semua kekurangan yang ada di siklus 1 menjadi pertimbangan dalam proses perencanaan siklus berikutnya agar proses pembelajaran lebih baik dan mencapai indikator keberhasilan

\section{Siklus II}

a. Tahap Perencanaan

Pada tahap ini mengacu pada hasil refleksi yang telah diperoleh dari siklus 1 . 
Beberapa perencanaan yang lebih difokuskan setelah menganalisis hasil refleksi pada siklus pertama seperti mengkondisikan siswa sehingga semua dapat terlibat dan aktif dalam proses pembelajaran terutama memecahkan persoalan matematika yang telah tersedia, melibatkan siswa dalam membantu menyediakan benda-benda konkret yang digunakan sebagai media pembelajaran, menyesuaikan bobot pelajaran dengan waktu pertemuan sehingga waktu menjadi efisien, sehingga tercapainya tujuan pembelajaran, memberikan motivasi kepada kelompok agar lebih aktif sehingga dapat bersaing dengan antar kelompok untuk menjadi yang terbaik, memberikan perhatian dan bimbingan yang lebih intensif pada siswa atau kelompok yang mengalami kesulitan atau terlihat pasif.

\section{b. Tahap Pelaksanaan}

Siklus kedua dalam proses pembelajaran masih dilengkapi dengan LKPD dan benda konkret dalam setiap kelompok agar pembelajaran tetap terarah. Siswa sudah terlihat aktif dalam berdiskusi dan tidak hanya mengandalkan satu orang. Siswa sudah tidak lagi bergantung serta mengandalkan orang lain atau siswa lain, kini sudah mulai beralih dengan penggunaan benda konkret sebagai pendukung dalam memecahkan permasalahan matematika. Benda konkret menjadi andalan siswa dalam memecahkan permasalahan matematika ataupun dalam mengkonfirmasi jawaban/kesimpulan.

Siswa juga sudah mulai terbiasa dengan mengaplikasian benda konkret dalam LKPD sehingga dapat langsung memahami pokok permasalahan yang kemudian merencanakan pemecahan masalah. Dilanjut dengan melaksanakan perencanaan tersebut sehingga dapat mendorong siswa mendapatkan ide/gagasan baru yang kemudian dapat disimpulkan dan ditulis kembali dalam LKPD.

\section{c. Tahap Pengamatan}

Hasil pengamatan yang diperoleh pada Siklus II menunjukkan bahwa penggunaan metode pembelajaran Problem solving sudah aktif dan efektif, dimana siswa sudah antusias mengikuti proses pembelajaran dengan metode Problem solving dan terlihat senang serta menikmati dalam penggunaan benda konkret pada proses pembelajaran. Siswa sudah dapat beradaptasi dengan pembelajaran problem solving sehingga menumbuhkan semangat dan antusias terhadap pemecahan masalah di dalam LKPD yang diberikan. Siswa juga lebih aktif dan percaya diri dalam belajar, serta sudah berani untuk bertanya kepada guru dan teman mengenai materi yang belum dimengerti, dan lebih saling menghargai dalam diskusi kelompok.

d. Tahap Refleksi

Berdasarkan hasil observasi yang telah diperoleh melalui pelaksanaan pembelajaran pada Siklus II, diperoleh beberapa hasil sebagai berikut:

1. Siswa sudah terlihat aktif dan lebih percaya diri terhadap ide/gagasan yang didapat.

2. Terjalinnya komunikasi yang baik antara siswa dengan siswa maupun dengan guru. 
3. Proses pembelajaran menjadi lebih efektif

4. Motivasi siswa dalam proses pembelajaran meningkat karena siswa didorong untuk belajar secara mandiri sehingga dapat mengeksplor pengetahuan serta ide/gagasan.

5. Suasana kegiatan belajar terlihat menyenangkan dan kreatif dengan adanya media pembelajaran benda konkret.

Untuk dapat mengetahui terjadinya peningkatan dari kemampuan berpikir kreatif matematis siswa, dapat dilihat dari rata-rata skor tes kemampuan berpikir kreatif matematis pada setiap siklus. Setiap siklus terdiri dari dari empat tahap yaitu tahap perencanaan, tahap pelaksanaan, tahap pengamatan dan tahap refleksi.

Pada siklus II, kelas diberikan perlakuan yang sama dengan menggunakan metode problem solving berbantu benda konkret pada materi garis dan sudut (hubungan antara sudut, dan melukis sudut istimewa). Namun pada Siklus II terdapat perbaikan tindakan yang kurang maksimal atau kesalahankesalahan pada siklus sebelumnya yang didapat melalui hasil diskusi dan juga obeservasi bersama kolaborator dan juga observer pada Siklus II sehingga hasil dapat terus ditingkatkan agar tercapainya tingkat keberhasilan yang sudah peneliti tentukan sebelumnya. Peneliti kembali melakukan tes berpikir kreatif siklus II. Kemampuan berpikir kreatif matematis siswa meningkat dari siklus I, dengan perolehan skor rata-rata yaitu 80,08 dan presentasi siswa yang mencapai kriteria tingkat keberhasilan hanya $84,84 \%$ yang artinya sudah mencapai kriteria tingkat keberhasilan yang sudah ditentukan oleh peneliti.

Tabel 1. Prosentase Indikator Keberhasilan Tiap Siklus

\begin{tabular}{|c|l|c|} 
No. & Kriteria & $\begin{array}{c}\text { Persentase Siswa } \\
\text { yang sudah } \\
\text { mencapai indikator } \\
\text { keberhasilan }\end{array}$ \\
\hline 1. & $\begin{array}{l}\text { Pra } \\
\text { Siklus }\end{array}$ & $36,36 \%$ \\
\hline 2. & Siklus I & $63,64 \%$ \\
\hline 3. & Siklus II & 84,84\% \\
\hline \multicolumn{2}{|c|}{ Hasil penelitian ini juga } \\
menunjukan bahwa tidak hanya
\end{tabular}
kemampuan berpikir kreatif siswa yang meningkat, akan tetapi kemampuan pemahaman konsep juga meningkat. Karena setelah siswa memecahkan masalah dengan menggunakan benda konkret, berdasarkan data yang diperoleh bahwa siswa juga mendapat pengetahuan baru tentang cara memecahkan persoalan matematika yang dapat disebut juga sebagai pemahan konsep. Hal ini sejalan dengan hasil penelitian (Fahrudin, Netriwati, \& Putra, 2018).

\section{PENUTUP}

\section{Simpulan}

Berdasarkan hasil penelitian yang telah diperoleh, maka dapat disimpulkan bahwa adanya peningkatan kemampuan berpikir kreatif matematis siswa dari sebelum diberikannya tindakan pada pra Siklus dan sesudah diberikan tindakan 
pada Siklus I dan Siklus II menggunakan metode problem solving dengan berbantu benda konkret. Faktor-faktor yang mempengaruhi kemampuan berpikir kreatif diantaranya motivasi belajar siswa bahwa pembelajaran tidak hanya bergantung pada orang lain, namun kita dapat mencari informasi secara mandiri seperti dengan penggunaan benda konkret, keaktifan dan keefektifan dalam belajar dengan menggunakan benda konkret.

Penerapan pembelajaran dengan menggunakan metode problem solving berbantu benda konkret dapat memberikan dampak positif sehingga dapat menjadikan peserta didik aktif dan antusias dalam proses pembelajaran, membangun rasa percaya diri peserta didik dalam mengemukakan pendapat atau sekadar bertanya kepada guru, serta dapat berkomunikasi baik dengan guru atau peserta didik lainnya dengan baik saat kegiatan diskusi. Peneliti mengharapkan dari adanya dampak positif ini guru dapat melanjutkan metode problem solving dengan berbantu benda konkret.

\section{DAFTAR PUSTAKA}

Djamarah, S. B., \& Zain, A. (2015). Strategi Belajar Mengajar. Jakarta: Rineka Cipta.

Faelasofi, R. (2017). Identifikasi Kemampuan Bepikir Kreatif
Matematika Pokok Bahasan Peluang. Jurnal Edumath, 115-163.

Faelasofi, R. (2017). Identifikasi Kemampuan Berpikir Kreatif Matematika Pokok Bahasan Peluang. Jurnal Edumath, 155-163.

Fahrudin, Netriwati, \& Putra, R. W. (2018). Pembelajaran problem solving modifikasi untuk meningkatkan kemampuan pemahaman konsep matematis siswa SMP. Jurnal Matematika, 181-189.

Firdausi, Asikin, M., \& Wuryanto. (2018). Analisis kemampuan berpikir kreatif siswa ditinjauh dari gaya belajar pada pembelajaran model Eliciting Activities (MEA). PRISMA, 239-247.

Firmansyah, Wonorahardjo, S., \& Arief, M. (2016). Penerapan model pembelajaran problem solving berbantu web pada materi ekstraksi terhadap hasil belajar dan motivasi mahasiswa. Jurnal pendidikan sains, 65-72.

Handayani, I., Supriadi, E., \& Marlena, L. (2018). Meningkatkan Kemampuan Pemahaman Konsep Matematika Mahasiswa Calon Guru dengan Menggunakan Dianes AEM pada Materi Persamaan Kuadat. Pendidikan Matematika, 479-488.

Hendriana, B. (2019). LEMBAR KERJA PESERTA DIDIK BERBASIS CABRI 3D UNTUK. AKSIOMA: Jurnal Program Studi Pendidikan Matematika, 112-120. 
Kuswana, W. S. (2011). Taksonomi Berpikir. Bandung: PT. Remaja Rosdakarya.

Lince, R. (2016). Cretive Thingking Ability to Increase Student Mathematical of Junior High School by Applying Models Numbered Heads Together. Journal of Education and Practice, 206-212.

Mulyatiningsih, E. (2011). Metode Penelitian Terapan Bidang Pendidikan. Bandung: ALFABETA.

Sadiman, A., \& dkk. (2014). Media Pendidikan: Pengertian, pengembangan, dan pemanfaatannya. Jakarta: PT. Raja Grafindo.

Setianingsih, H. (2016). Keefektifan problem solving dan guided inquiry dalam setting TAl ditinjau dari prestasi belajar, kemampuan berpikir kritis, dan kedisiplinan diri. Jurnal riset pendidikan matematika, 221-233.

Shoimin, A. (2014). 68 Model-model Pengajaran dan Pembelajaran. Yogyakarta: Ar-Ruzz Media.

Siswono, T. Y. (2018). Pembelajaran Matematika Berbasis Pengajuan dan Pemecahan Masalah. Surabaya: PT. Remaja Rosdakarya.

Sudjana, N., \& Rivai, A. (2010). Media Pengajaran. Bandung: Sinar Baru Algesindo.

Uno, H. B., Umar, M. K., \& Panjaitan, K. (2014). Variabel Penelitian dalam Pendidikan dan Pembelajaran. Jakarta: PT. Ina Publikatama.



